\title{
UV-Vis Spectrophotometric Analysis and Light Irradiance Through Hot-Pressed and Hot-Pressed-Veneered Glass Ceramics
}

\author{
Myrna Carvalho DIAS ${ }^{1}$ \\ Evandro PIVA ${ }^{2}$ \\ Rafael Ratto de MORAES ${ }^{1}$ \\ Gláucia Maria Bovi AMBROSANO ${ }^{3}$ \\ Mário Alexandre Coelho SINHORETI ${ }^{1}$ \\ Lourenço CORRER-SOBRINHO ${ }^{1}$ \\ ${ }^{1}$ Department of Restorative Dentistry, Dental Materials Division, Dental School of Piracicaba, \\ State University of Campinas, Piracicaba, SP, Brazil \\ ${ }^{2}$ Department of Restorative Dentistry, Dental School, Federal University of Pelotas, RS, Brazil \\ ${ }^{3}$ Department of Community Dentistry and Biostatistics, Dental School of Piracicaba, \\ State University of Campinas, Piracicaba, SP, Brazil
}

\begin{abstract}
This study evaluated the irradiance of curing units through core and veneered hot-pressed ceramics as well as the transmittance of these materials. Discs of 0.7, 1.4 and $2 \mathrm{~mm}$ in thickness of Empress (EMP) and Empress Esthetic (EST), and $0.8(\mathrm{n}=5)$ and $1.1 \mathrm{~mm}(\mathrm{n}=5)$ thickness of Empress 2 (E2) were obtained. For E2, two of the 0.8-mm-thick discs were covered with dentin (1.2- and 1.4-mm-thick) and two with dentin + enamel (1.5-mm-thick). The 1.1-mm-thick specimens were submitted to the same veneering procedures. Specimens were evaluated by UV-Vis transmittance analysis and the percentage of transmittance was recorded. Irradiance through each specimen was evaluated with a quartz-tungsten-halogen (QTH), used in continuous or intermittent exposure modes, or a blue lightemitting diode (LED). Data were analyzed by Dunnett's test, ANOVA and Tukey's test at 5\% significance level. Exposure through ceramic decreased the irradiance for all ceramics. Irradiance through EST was significantly higher than through EMP. For E2, reduction in irradiance depended on the core and/or veneer thickness. The QTH intermittent mode showed higher irradiance than the continuous mode, and both showed higher irradiance than LED. The ceramic significantly influenced irradiance and transmittance, which were found to decrease with the increase in thickness.
\end{abstract}

Key Words: ceramic, dental materials, irradiance, light-curing units, transmittance.

\section{INTRODUCTION}

High-technology processes have led to the development of a wide range of dental ceramics. These materials use different approaches in an attempt to improve the mechanical properties of ceramics without being detrimental to their esthetic qualities (1). Some of the most representative materials are the glass and aluminum/zirconium oxide ceramics. IPS Empress (EMP) and Empress 2 (E2) are two well-known hot- pressed materials and, more recently, IPS Empress Esthetic (EST) was introduced (2).

EMP is a leucite-reinforced glass ceramic designed for restoring single units including veneers, inlays, onlays and crowns $(1,3)$. E2 was developed to produce crown and anterior bridge substructures $(1,4)$, due to its lithium disilicate-based microstructure, with high amounts of crystals dispersed within the glassy matrix (3). EST is also a leucite-based material, however with smaller crystals distributed in a more homo-

Correspondence: Prof. Dr. Lourenço Correr-Sobrinho e Prof. Dr. Mário Alexandre Coelho Sinhoreti, Faculdade de Odontologia de Piracicaba, UNICAMP, Área Materiais Dentários, Avenida Limeira, 901, 13414-903 Piracicaba, SP, Brasil. Tel: +55-19-2106-5348. Fax: +55-19-2106-5218. e-mail: sobrinho@fop.unicamp.br ou sinhoret@fop.unicamp.br 
geneous mode than EMP (2). On the other hand, the veneering ceramic applied to E2 cores is composed of fluorapatite crystals precipitated in a glassy matrix (3).

Due to the brittle characteristic of ceramics, resin-based cements are usually used for luting procedures. Many of the available resin cements are dualcured, polymerizing chemically upon mixing of a base and catalyst components and also when exposed to a polymerizing light, due to the presence of a photoinitiator (5). This molecule is excited in the presence of light with an adequate wavelength and sufficient irradiance $(6,7)$. In order to obtain high bond strengths after cementation, it is necessary that adequate light energy reaches the luting agent to ensure optimal polymerization (8).

Nonetheless, several investigators have reported the light attenuation effect promoted by ceramics $(5,9$ 13). The degree of this attenuation is primarily dependent on the characteristics of the restorative material, such as its composition, thickness, opacity and shade $(5,10,11)$. The combination of scattering, reflecting and absorbing properties at the outer surface of the intervening material may explain the reduction in the incident light (14). Several studies have evaluated the effect on irradiance for light passing through ceramic. However, few evaluations are reported in literature regarding the transmittance characteristics of ceramics and their relationship with the attenuation of the polymerizing light.

The aim of this in vitro study was to evaluate the light irradiance of curing units through core and veneered hot-pressed ceramics of different thickness and also to evaluate the transmittance of these materials. The tested hypothesis was that increased ceramic thicknesses would lead to decreased transmittance and irradiance.

\section{MATERIAL AND METHODS}

The glass ceramics evaluated were EMP, E2, EST, and IPS Eris for E2 dentin (D) and enamel (E), all from Ivoclar Vivadent AG (Schaan, Liechtenstein). For EMP and EST, 3 discs with $10 \mathrm{~mm}$ in diameter and 0.7, 1.4 or $2 \mathrm{~mm}$ in thickness were obtained. For E2, discs with $10 \mathrm{~mm}$ in diameter and $0.8(\mathrm{n}=5)$ or $1.1 \mathrm{~mm}$ in thickness $(n=5)$ were obtained, and divided according to the veneering material ( $\mathrm{D}$ or $\mathrm{E}$ ) to be applied, as shown in Figure 1. The dimensions of each specimen were confirmed with a digital caliper (Mitutoyo, Tokyo,
Japan) accurate to $0.01 \mathrm{~mm}$.

\section{Diffuse Light Transmittance Analysis}

Diffuse light transmittance measurements were performed in the 300 to $600 \mathrm{~nm}$ wavelength range using a UV-Vis (ultraviolet-visible) spectrophotometer (Lambda 9; Perkin Elmer, Shelton, CT, USA), equipped with an integrating sphere. A black rectangular cardboard segment $(4 \times 4 \mathrm{~cm})$ with a central orifice of $10 \mathrm{~mm}$ in diameter was used to position the specimens in front of the sphere holder. Data were recorded with a computer connected to the spectrophotometer, and a graph of light transmittance percentage per nanometer was obtained by using Origin 6.1 software (Microcal Software Inc, Northampton, MA, USA) for each ceramic specimen).

\section{Light Irradiance Analysis}

The irradiance through the ceramic specimens was evaluated using two light-curing units: a quartztungsten-halogen (XL2500; 3M ESPE, St. Paul, MN, USA) and a blue light-emitting diode (Ultrablue Is; DMC Equip. Ltda., São Carlos, SP, Brazil). The irradiance level was assessed with a handheld radiometer (model 100; Demetron Kerr, Orange, CA, USA), under controlled humidity $(50 \pm 10 \%)$ and temperature $\left(23 \pm 2^{\circ} \mathrm{C}\right)$ conditions. The light-curing units were connected to a voltage stabilizer and the light guide tip was placed

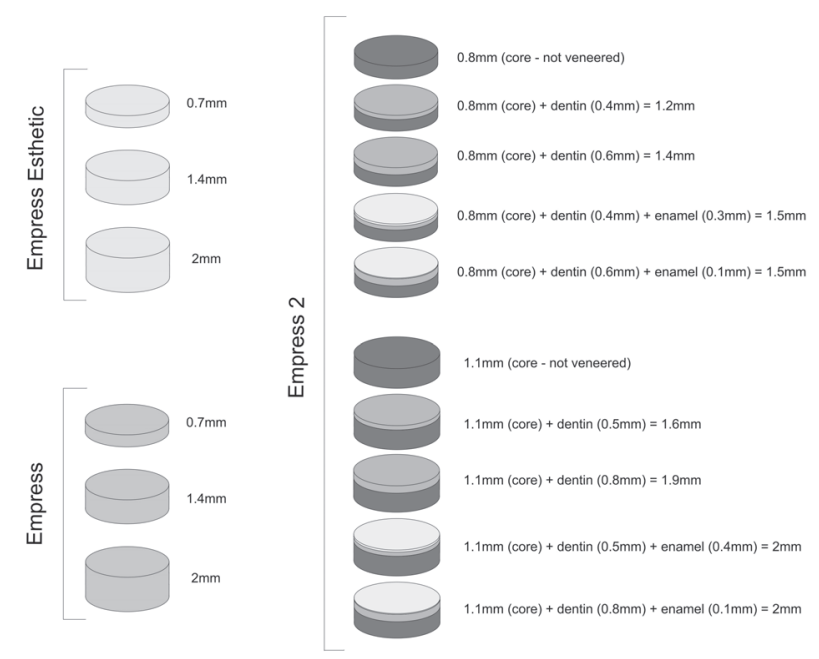

Figure 1. Description of the ceramic specimens evaluated in the study. 
perpendicular to the radiometer detector (control group) or directly onto to the surface of the ceramic discs.

Ten exposures of $40 \mathrm{~s}$ each were sequentially carried out and the irradiance was recorded every $10 \mathrm{~s}$. Additionally to the continuous exposure mode, for the QTH unit, an intermittent method was tested, in which each $40 \mathrm{~s}$ exposure was started only after stopping the

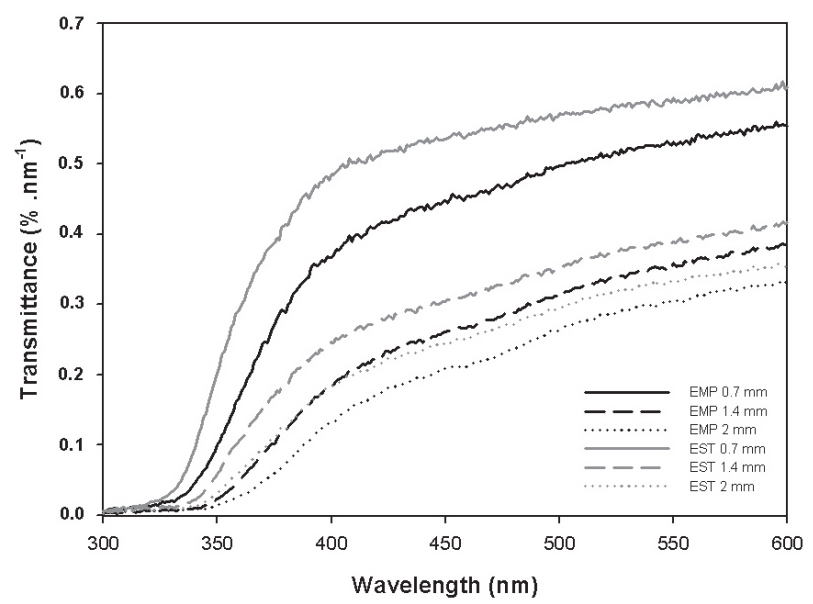

Figure 2. UV-Vis spectrum of IPS Empress (EMP) and Empress Esthetic (EST). Decreased transmittance was observed with the increase in ceramic thickness. When comparing EMP and EST within each thickness, EMP always showed lower transmittance, irrespective of the wavelength. curing unit cooling fan. Data for EMP and EST groups were submitted to a $2 \times 3 \times 3$ factorial design ANOVA (ceramic $\mathrm{x}$ thickness $\mathrm{x}$ curing method), with 3 additional treatments (control for each curing method). The factors were compared to their respective control groups by Dunnett's test, and between each other with Tukey's test. Data for E2 core and veneered groups were submitted to an 11 × 3 factorial design ANOVA (ceramic x light-curing unit), followed by Tukey's test. All statistical analyses were conducted at a significance level of $\mathrm{p}<0.05$.

\section{RESULTS}

\section{Diffuse Light Transmittance}

The results of light transmittance through EMP and EST specimens are shown in Figure 2, and through core and veneered E2 are shown in Figure 3. There was a reduction in percentage of light transmittance depending on the thickness of the ceramic. EST specimens showed higher percentage of light transmittance than EMP for all thicknesses. This reduction was higher for E2 specimens veneered with D compared to E2+D specimens veneered with E. Furthermore, in both Figures 2 and 3, it can be observed that the transmittance percentage increased with increased wavelength, irrespective of the ceramic material or thickness.

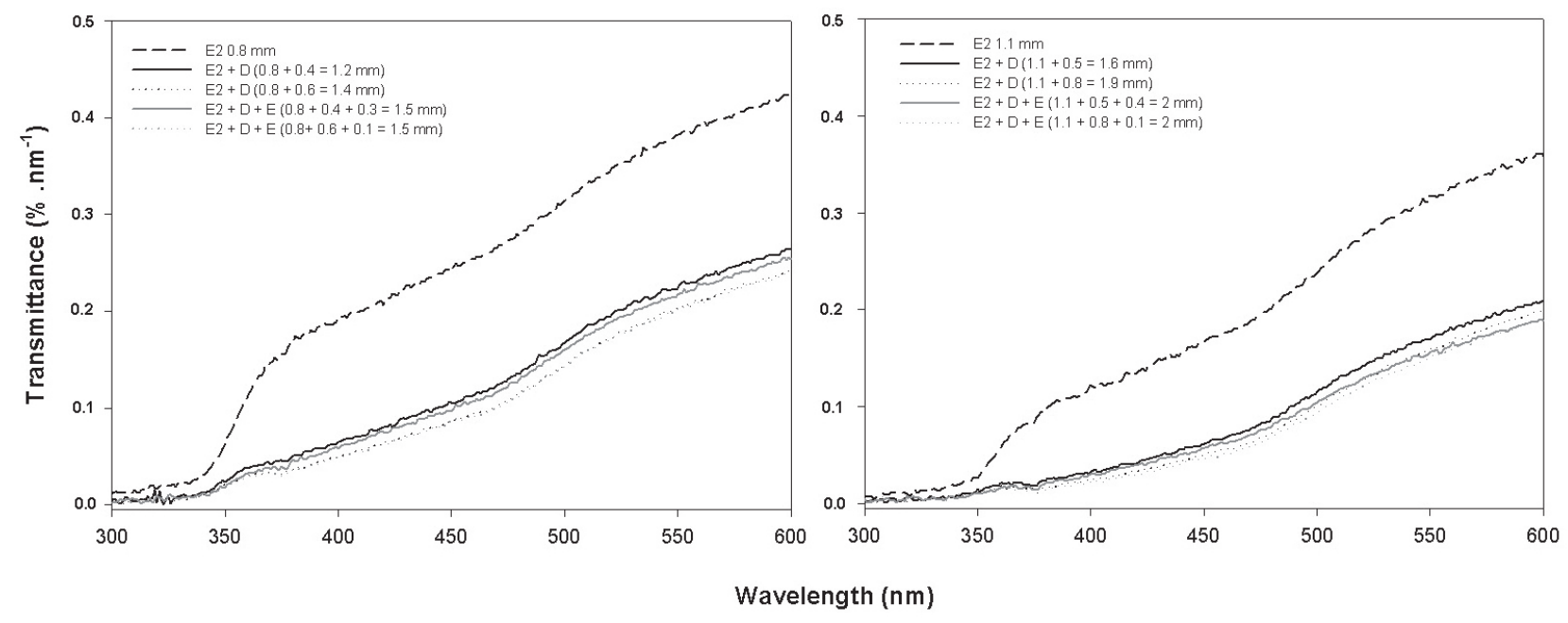

Figure 3. UV-Vis spectrum of IPS Empress 2 (E2) core and specimens veneered with dentin (D) or dentin/enamel (D+E). Decreased irradiance was detected with the increase in ceramic thickness. The increase in thickness presented greater effect in attenuating the transmittance than the veneer material (dentin or dentin/enamel). 


\section{Light Irradiance}

The results for EMP and EST specimens are shown in Table 1. All groups irradiated through ceramic showed a significant reduction in light irradiance when compared to the control group $(\mathrm{p}<0.05)$, with a gradual reduction as a function of increasing ceramic thickness. However, the irradiance through EST was significantly higher than through EMP $(\mathrm{p}<0.05)$, irrespective of the ceramic thickness or curing method. In addition, the QTH intermittent mode showed significantly higher irradiance than the continuous mode ( $p<0.05$ ), regardless of the ceramic material or thickness. Furthermore, the LED unit showed significantly lower irradiance than the QTH unit $(\mathrm{p}<0.05)$, even when the QTH was used in the continuous mode.

The results for E2 core and veneered specimens are shown in Table 2. All groups showed a significant reduction in light irradiance, which was dependent on the core and/or veneer ceramic thickness, when compared to the control group $(\mathrm{p}<0.05)$. Irrespective of the curing method, irradiance through $\mathrm{E} 2$ with $0.8 \mathrm{~mm}$ was significantly higher than irradiance through $1.1 \mathrm{~mm}$ $(\mathrm{p}<0.05)$. Both E2 specimens veneered with D and D+E caused a significant and gradual reduction in light

Table 1. Means (standard deviation) for irradiance $\left(\mathrm{mW} / \mathrm{cm}^{2}\right)$ through IPS Empress and IPS Empress Esthetic specimens.

\begin{tabular}{lcccc}
\hline \multirow{2}{*}{ Group } & Exposure mode & \multicolumn{3}{c}{ Ceramic thickness } \\
\cline { 3 - 5 } & & $0.7 \mathrm{~mm}$ & $1.4 \mathrm{~mm}$ & $2.0 \mathrm{~mm}$ \\
\cline { 3 - 5 } Empress & QTH continuous & $355(19) \mathrm{A}, \mathrm{b}$ & $218(9) \mathrm{B}, \mathrm{b}$ & $149(8) \mathrm{C}, \mathrm{b}$ \\
& QTH intermittent & $354(4) \mathrm{A}, \mathrm{a}$ & $247(4) \mathrm{B}, \mathrm{a}$ & $160(4) \mathrm{C}, \mathrm{a}$ \\
& LED & $262(7) \mathrm{A}, \mathrm{c}$ & $163(3) \mathrm{B}, \mathrm{c}$ & $106(2) \mathrm{C}, \mathrm{c}$ \\
& & & & \\
Esthetic & QTH continuous & $422(17) \mathrm{A}, \mathrm{b}$ & $263(13) \mathrm{B}, \mathrm{b}$ & $188(8) \mathrm{C}, \mathrm{b}$ \\
& QTH intermittent & $457(6) \mathrm{A}, \mathrm{a}$ & $289(3) \mathrm{B}, \mathrm{a}$ & $205(2) \mathrm{C}, \mathrm{a}$ \\
& LED & $309(9) \mathrm{A}, \mathrm{c}$ & $189(4) \mathrm{B}, \mathrm{c}$ & $134(3) \mathrm{C}, \mathrm{c}$ \\
& & & & \\
Control & QTH continuous & & $852(26)^{*}$ & \\
& QTH intermittent & & $525(10)^{*}$ & \\
& LED & & & \\
\hline
\end{tabular}

Means followed by different uppercase letters in the same row and lowercase letters in the same column were significantly different (Tukey's test, $\mathrm{p}<0.05$ ). *All groups were significantly different from their respective control groups (Dunnett's test, $\mathrm{p}<0.05)$. irradiance $(\mathrm{p}<0.05)$ with increasing the veneer thickness. Moreover, the QTH intermittent mode showed higher irradiance through 1.2, 1.4 and $1.5 \mathrm{~mm}$-thick veneered specimens than LED and QTH continuous modes $(\mathrm{p}<0.05)$, although similar findings were detected for all exposure modes when irradiance was carried out through 1.6, 1.9 and 2 mm-thick veneered ceramics.

\section{DISCUSSION}

The present results show a significant attenuation of irradiance and transmittance through almost all ceramic specimens. In a clinical situation, this may account for lower light energy reaching the cement layer during luting procedures, potentially resulting in poor polymerization. The curing reaction is initiated and sustained when light energy of sufficient intensity and suitable wavelength excites a great number of photoinitiator molecules, thus producing a sufficient number of free radicals $(6,7)$. Inadequate curing leads to poor mechanical properties and increased solubility of the cement $(5,12)$, which may result in debonding of ceramic restoration over the course of time (9).

In addition, the present outcomes showed that the decrease in light irradiance and transmittance were dependent upon the ceramic thickness, confirming the tested hypothesis. This arises from the fact that the translucency/opacity of a ceramic is dictated by its thickness. The thicker the specimen, the more opaque is the material and, as a consequence, lower light energy can be transmitted through it (14-16). In addition to thickness, the presence of specific elements also contributes to an increased opacity, as observed for E2 veneered with $D$. The addition of titanium oxide to obtain a yellowbrown shade that matches that of the natural teeth increases the light absorption (17).

When comparing EST and EMP specimens, the transmittance and irradiance through EST was always significantly higher than 
through EMP, for all thicknesses. The amount of the light being absorbed, reflected and transmitted depends in large part on the amount of crystals within the glassy matrix $(14,15,17)$ and the size of the particles compared with the incident light wavelength $(14,17)$. Although glass ceramics reinforced with leucite crystals present fewer amounts of grains - $35 \pm 5 \mathrm{vol} \%$ of leucite for EMP in comparison with $70 \pm 5 \mathrm{vol} \%$ of lithium disilicate for E2 (3) -, the size of the leucite crystals dispersed within the EST glassy matrix allowed a high amount of light to pass through it. However, a maximum scattering effect occurs when the size of the crystal is approximately half of (18) or similar (14) to the incident light wavelength.

Another factor that interferes with light transmission is the difference in the refractive index between the crystals and the glassy matrix. The refractive index is a measure for how much the speed of light is reduced inside a medium; a maximum scattering effect is expected when there is a large mismatch between the index of the particles and the glassy matrix itself. Leucite [1.51] and lithium disilicate [1.55] have similar indexes to the glassy matrix [1.50] $(14,19)$. However, the presence of porosity in these glass ceramics might have a higher influence on the light transmission than the particles themselves. The mismatch between the re-

Table 2. Means (standard deviation) for irradiance $\left(\mathrm{mW} / \mathrm{cm}^{2}\right)$ through IPS Empress 2 core and veneered specimens.

\begin{tabular}{lccc}
\hline \multirow{2}{*}{ Group } & \multicolumn{3}{c}{ Ceramic thickness } \\
\cline { 2 - 4 } & $\begin{array}{c}0.7 \mathrm{~mm} \\
\text { (QTH - cont. })\end{array}$ & $\begin{array}{c}1.4 \mathrm{~mm} \\
\text { (QTH intermit. })\end{array}$ & $\begin{array}{c}2.0 \mathrm{~mm} \\
\text { (LED) }\end{array}$ \\
\hline Control & $752(27) \mathrm{B}, \mathrm{a}$ & $802(10) \mathrm{A}, \mathrm{a}$ & $525(12) \mathrm{C}, \mathrm{a}$ \\
E2 $(0.8 \mathrm{~mm})$ & $224(10) \mathrm{B}, \mathrm{b}$ & $237(3) \mathrm{A}, \mathrm{b}$ & $154(4) \mathrm{C}, \mathrm{b}$ \\
E2 $(1.1 \mathrm{~mm})$ & $149(7) \mathrm{B}, \mathrm{c}$ & $161(3) \mathrm{A}, \mathrm{c}$ & $104(2) \mathrm{C}, \mathrm{c}$ \\
E2+D $(0.8+0.4=1.2 \mathrm{~mm})$ & $69(4) \mathrm{AB}, \mathrm{d}$ & $77(2) \mathrm{A}, \mathrm{d}$ & $60(2) \mathrm{B}, \mathrm{d}$ \\
$\mathrm{E} 2+\mathrm{D}(0.8+0.6=1.4 \mathrm{~mm})$ & $53(3) \mathrm{AB}, \mathrm{ff}$ & $61(2) \mathrm{A}, \mathrm{e}$ & $47(2) \mathrm{B}, \mathrm{e}$ \\
E2 + D $(1.1+0.5=1.6 \mathrm{~mm})$ & $33(3) \mathrm{A}, \mathrm{g}$ & $36(2) \mathrm{A}, \mathrm{g}$ & $28(2) \mathrm{A}, \mathrm{f}$ \\
E2 + D $(1.1+0.8=1.9 \mathrm{~mm})$ & $17(2) \mathrm{A}, \mathrm{h}$ & $20(1) \mathrm{A}, \mathrm{h}$ & $16(1) \mathrm{A}, \mathrm{g}$ \\
$\mathrm{E} 2+\mathrm{D}+\mathrm{E}(0.8+0.4+0.3=1.5 \mathrm{~mm})$ & $61(4) \mathrm{AB}, \mathrm{de}$ & $70(2) \mathrm{A}, \mathrm{de}$ & $54(2) \mathrm{B}, \mathrm{de}$ \\
E2 + D + E $(0.8+0.6+0.1=1.5 \mathrm{~mm})$ & $50(4) \mathrm{B}, \mathrm{f}$ & $57(1) \mathrm{A}, \mathrm{f}$ & $44(2) \mathrm{B}, \mathrm{e}$ \\
E2 + D + E $(1.1+0.5+0.4=2.0 \mathrm{~mm})$ & $25(2) \mathrm{A}, \mathrm{g}$ & $30(2) \mathrm{A}, \mathrm{g}$ & $23(1) \mathrm{A}, \mathrm{fg}$ \\
E2 + D + E $(1.1+0.8+0.1=2.0 \mathrm{~mm})$ & $16(2) \mathrm{A}, \mathrm{h}$ & $18(1) \mathrm{A}, \mathrm{h}$ & $14(1) \mathrm{A}, \mathrm{g}$ \\
\hline
\end{tabular}

Empress 2 =E2; $\mathrm{D}=$ dentin; $\mathrm{E}=$ enamel. Means followed by different uppercase letters in the same row and lowercase letters in the same column, were significantly different (Tukey's test, $\mathrm{p}<0.05$ ). fractive index of the pore [1.00] and of the glassy matrix $(14,17,19)$ may lead to a significant light scattering effect (14).

With respect to the veneering technique, the present outcomes indicate that the ceramic thickness presented greater effect in decreasing the light irradiance and transmittance than the veneer material (dentin or dentin/enamel). Other factors might affect the light transmission, such as changes in the constituents of the core material because of additional firing cycles, porosity between the layers, or reflectance at the interface between core and veneering ceramic (19). Nonetheless, Cattell et al. (4) contest the idea that an increase in the crystalline content of $\mathrm{E} 2$ veneered with the D+E occurs during firing cycles. These authors (4), by means of Xray diffraction analysis, detected no significant crystalline phase change for the core ceramic when it was submitted to firing cycles of the veneering materials.

Moreover, it was observed that the light transmittance increased with the increase of wavelength. This result is in accordance with the Rayleigh scattering equation (16), which states that higher scattering occurs at lower wavelengths. This observation is important when considering the spectral emission of curing units and also the absorbance peak of the photoinitiator. For instance, camphorquinone has an absorbance peak at $468 \mathrm{~nm}(6,7)$, phenyl-propanedione (PPD) at $410 \mathrm{~nm}$, bisacylphosphine oxide (BAPO) from 320 to $390 \mathrm{~nm}$, and triacylphosphine oxide (TPO) at 381 $\mathrm{nm}$ (7). Therefore, camphorquinonecontaining resins would potentially be more properly polymerized beneath ceramics than those containing PPD, BAPO or TPO because of the higher attenuation of the transmittance that occurs at lower wavelengths.

With regard to the light-curing pro- 
cedures, the QTH intermittent mode generally showed significantly higher irradiance than the continuous mode. The large amount of infrared light emitted from QTH units produces great amount of heat, which is filtered out and discarded by means of intense fan-cooling (6). Often, not only the summation of light energy, but also the additional thermal increase is responsible for conversion (7). However, the absence of an adequate stream of cooling air through the unit may predispose early bulb failure and cause a decrease in light intensity over the course of time (6). The present results show that allowing the fan cooling to operate without interruption is effective in optimizing the irradiance level.

On the other hand, the LED unit showed significantly lower irradiance than the QTH unit, even when the latter was used in the continuous mode, except for E2 veneered. It has been previously reported that LED units are the most efficient ones, because they are capable of converting electrical current into the correct wavelength, similar to the absorption wavelength of camphorquinone (19). However, in addition to the spectral emission within the blue region of the visible spectrum (400 to $515 \mathrm{~nm}$ ), sufficient irradiance level should be emitted by the curing unit $(6,7)$. Therefore, care should be taken when polymerizing resin luting agents beneath ceramic restorations, irrespective of the light-curing unit used.

It may be concluded that the ceramic material presented a significant influence on light irradiance and transmittance, which were found to decrease with the increase in ceramic thickness. The QTH intermittent exposure mode produced higher irradiance than the continuous exposure mode, and both modes showed higher irradiance through ceramic compared to the LED curing unit.

\section{RESUMO}

Este estudo avaliou a irradiância de unidades de fotoativação através de cerâmicas para subestrutura com e sem cobertura, e a transmitância desses materiais. Discos de 0,7, 1,4 e $2 \mathrm{~mm}$ de espessura de Empress (EMP) e Empress Esthetic (EST), e de 0,8 $(n=5)$ e $1,1 \mathrm{~mm}(\mathrm{n}=5)$ de espessura de Empress 2 (E2) foram obtidos. Para E2, dois discos de $0,8 \mathrm{~mm}$ foram cobertos com dentina (1,2 e 1,4 mm de espessura) e dois com dentina + esmalte (1,5 mm de espessura). Os discos de 1,1 $\mathrm{mm}$ de espessura foram submetidos aos mesmos procedimentos de cobertura. Os espécimes foram avaliados por análise de transmitância UV-Vis e o percentual de transmitância foi registrado. A irradiância através dos discos foi avaliada com fonte de luz de lâmpada halógena de quartzo-tungstênio (QTH), utilizada nos modos contínuo ou intermitente, e diodo emissor de luz (LED). Os dados foram analisados com testes de Dunnett, ANOVA e Tukey com nível de significância de 5\%. A exposição através da cerâmica reduziu a irradiância para todas as cerâmicas. A irradiância através de EST foi maior que EMP. Para E2, a redução dependeu da espessura da subestrutura e/ou cobertura. O modo intermitente para QTH mostrou maior irradiância que o modo contínuo; ambos apresentaram maior irradiância que oLED. A cerâmica influenciou significativamente a irradiância e transmitância, que diminuíram com o aumento da espessura.

\section{ACKNOWLEDGEMENTS}

The authors are grateful to $\mathrm{CNPq} / \mathrm{Brazil}$ for the financial support (Grants 142795/2005-4 and 308128/2006-0), and to Mr. Antônio Carlos Costa for the assistance with the transmittance analysis.

\section{REFERENCES}

1. Guazzato M, Albakry M, Ringer SP, Swain MV. Strength, fracture toughness and microstruture of a selection of allceramic materials. Part I. Pressable and alumina glass-infiltrated ceramics. Dent Mater 2004;20:441-448.

2. Bühler-Zemp P. IPS Empress Esthetic - Scientific Documentation 2004; Ivoclar Vivadent AG, Schaan, Liechtenstein.

3. Höland W, Schweiger M, Frank M, Rheinberger V. A comparison of the microstruture and properties of IPS Empress 2 and the IPS Empress glass-ceramics. J Biomed Mater Res 2000;53:297-303.

4. Cattell MJ, Palumbo RP, Knowles JC, Clarke RL, Samarawickrama DY. The effect of veneering and heat treatment on the flexural strength of Empress 2 ceramics. J Dent 2002;30:161-169.

5. el-Mowafy OM, Rubo MH, el-Badrawy WA. Hardening of new resin cements cured through a ceramic inlay. Oper Dent 1999;24:38-44.

6. Rueggeberg F. Contemporary issues in photocuring. Compend Contin Educ Dent 1999;20:14-15.

7. Stansbury JW. Curing dental resins and composites by photopolymerization. J Esthet Dent 2000;12:300-308.

8. Moraes RR, Correr-Sobrinho L, Sinhoreti MA, PuppinRontani RM, Ogliari FA, Piva E. Light-activation of resin cement through ceramic: relationship between irradiance intensity and bond strength to dentin. J Biomed Mater Res B Appl Biomater 2008;85:160-165.

9. Barghi N, McAlister EH. LED and halogen lights: effect of ceramic thickness and shade on curing luting resin. Compend Contin Educ Dent 2003;24:497-504.

10. Tango RN, Sinhoreti MA, Correr AB, Correr-Sobrinho L, Consani RL. Effect of veneering materials and curing methods on resin cement knoop hardness. Braz Dent J 2007; 18:235-239.

11. Cardash HS, Baharav H, Pilo R, Ben-Amar A. The effect of porcelain color on the hardness of luting composite resin cement. J Prosthet Dent 1993;69:620-623.

12. Jung H, Friedl KH, Hiller KA, Furch H, Bernhart S, Schmalz G. Polymerization efficiency of different photocuring units through ceramic discs. Oper Dent 2006;31:68-77. 
13. Rasetto FH, Driscoll CF, von Fraunhofer JA. Effect of light source and time on the polymerization of resin cement through ceramic veneers. J Prosthodont 2001;10:133-139.

14. Heffernan MJ, Aquilino SA, Diaz-Arnold AM, Haselton DR, Stanford CM, Vargas MA. Relative translucency of six allceramic systems. Part I: core materials. J Prosthet Dent 2002;88:4-9.

15. Antonson SA, Anusavice KJ. Contrast ratio of veneering and core ceramics as a function of thickness. Int $\mathrm{J}$ Prosthodont 2001;14:316-320.

16. Brodbelt RH, O'Brien WJ, Fan PL. Translucency of dental porcelains. J Dent Res 1980;59:70-75.
17. Zhang Y, Griggs JA, Benham AW. Influence of power/liquid mixing ratio on porosity and translucency of dental porcelains. J Prosthet Dent 2004;91:128-135.

18. Ruyter IV, Oysaed H. Conversion in different depths of ultraviolet and visible light composite materials. Acta Odontol Scand 1982;40:179-192.

19. Heffernan MJ, Aquilino SA, Diaz-Arnold AM, Haselton DR, Stanford CM, Vargas MA. Relative translucency of six allceramic systems. Part II: core and veneer materials. J Prosthet Dent 2002;88:10-15.

Accepted June 12, 2008 